\title{
“ThE PLACE WHERE BLOOM IS IN THE RESTAURANT": FRENCH TRANSLATIONS OF THE "SANDWICH" PASSAGE OF ULYSSES
}

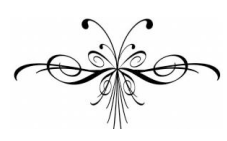

\section{SCARLETT BARON}

7 here are, to date, only two translations of Ulysses into French. The 1929 "authorized" translation by "M. Auguste Morel, assisté par Stuart Gilbert, entièrement revue par Valery Larbaud et l'auteur", published by Adrienne Monnier's La Maison des Amis des Livres, ${ }^{1}$ was the only French version for over seven decades. The cultural monopoly achieved by Morel's text resulted in part from the widespread conviction that the translation he had produced was exceptionally good - a conception powerfully bolstered by the fact of Joyce's and Larbaud's involvements in the project. These contributions by the author and by "l'un des plus grands stylistes français" ${ }^{2}$ ensured that the published translation be-

References to Ulysses are to the Gabler edition:

James Joyce, Ulysses, ed. Hans Walter Gabler with Wolfhard Steppe and Claus Melchior (New York: Random House, 1986).

These are given in parentheses in the main body of the text in the following form:

( $U$ episode number. line number).

${ }^{1}$ James Joyce, Ulysses, trans. Auguste Morel with the assistance of Stuart Gilbert, revd by Valery Larbaud in collaboration with the author (Paris: Maison des Amis des Livres, 1929). This text is reprinted in James Joyce, Oeuvres, ed. Jacques Aubert, "Bibliothèque de la Pléiade", 2 vols (Paris: Gallimard, 1982-1995), vol. 2 (1995) - hereafter abbreviated as "Pléiade" 2.

${ }^{2}$ This assessment of Larbaud was widespread in the 1920s, when Larbaud enjoyed greater fame and esteem than he has done in posterity. In this instance, the words are Stuart Gilbert's, as featured in a note he attached to a number of handwritten documents relating to the 1929 translation, now at the Harry Ransom Research Centre at the University of Texas at Austin. See John L. Brown, "Ulysses into French", in Joyce at Texas, Essays on the 
came invested with near-canonical status in the French-speaking world. According to Jacques Aubert, Joyce's responses to queries by Stuart Gilbert and Larbaud "dûment intégrées à la traduction française, ont fait de celle-ci une référence pour l'exégèse et la critique au-delà même de nos frontières". ${ }^{3}$

In 1995, Aubert's edition of Joyce's Oeuvres for the prestigious French "Pléiade" collection published by Gallimard, opted to reprint Morel's translation, rather than to produce a new, rival text. In support of this decision, Aubert's editorial note emphasizes the eminent position occupied by the first (and, at the time, only) translation in the French literary consciousness. The choice not to attempt a new translation, sixty years on, derived, as he claimed, from a recognition of "la place qu'elle occupe dans la littérature française, dont elle constitue un moment et un monument". 4

Morel's text stands tel quel in the second of the two "Pléiade" volumes devoted to Joyce, with a couple of notable exceptions. The first difference concerns typography: the "Pléiade" (being the established, conservative collection that it is) allows for no deviation from its house-styling conventions, and refused to defer to Joyce's dislike for what he called "perverted commas". 5 Aubert can only warn that this particular Joycean principle is disregarded in the text he presents. ${ }^{6}$ The second significant difference between this edition and the 1929 text resides in its provision of a great wealth of excellent annotations. The notes supplied fill 900 pages in the small print the "Pléiade" reserves for extraneous materials. This meticulously compiled body of information constitutes an invaluable companion to the translated text, indicating important emendations made to the 1922 English Ulysses by the Gabler edition of 1984 and elucidating many of the countless interpretative and contextual cruxes that have exercised the vast field of Joycean criticism since 1929. This ample annotative apparatus offers an honest and illuminating record of the some of the layers of meaning that are inevitably lost in the process of translation. In a sense, these notes turn the 1995 "Pléiade" reprint of Morel's text into a translation event in its own right: the French Ulysse, if read in conjunction with these extensive supplementary materials, constitutes a radically different experience from that of an encounter with

James Joyce Materials at the Humanities Research Centre, ed. Dave Oliphant and Thomas Zigal (Austin, Texas: Humanities Research Centre, The University of Texas at Austin, 1983), pp. 29-59, p. 30, and "Pléiade" 2, p. 1032.

3 "Pléiade" 2, p. 1032.

4 "Pléiade" 2, p. 1032.

${ }^{5}$ Letter to Harriet Shaw Weaver, 11 July 1924, in Letters of James Joyce, 3 vols (19571966), vol. 3, ed. Richard Ellmann (New York: Viking Press, 1966), p. 99.

${ }^{6}$ James Joyce, Oeuvres, ed. Jacques Aubert, "Pléiade" 2, 2 vols (Paris: Gallimard, 19821995), vol. 1 (1982), p. cxxi.

Scientia Traductionis, n.8, 2010 
the reading text alone. That said, this positive assessment of the edition's contribution can easily be turned inside out. Indeed, the efforts made by Aubert and his team to account for the meanings left out by the 1929 translation - an account which, though extensive, could not possibly be exhaustive beg the question: had the time not in fact come for a French translation which would endeavour to incorporate some of the critical knowledge and textual changes accumulated over the course of Ulysses's twentieth-century history - for a "second-generation" Ulysse to revise some of the necessarily "naïve" decisions made by the early translators?"

Perhaps at least in part in answer to this question, a second French translation was quick to follow. ${ }^{8}$ Timed to coincide with the 2004 Bloomsday centenary, the new translation - which was overseen by Aubert and published by Gallimard in its "Du Monde Entier" collection" - was driven by several stated objectives. One of its professed aims was to remedy the oversights of the first translation, which had been published relatively soon after its English original. The idea was to compensate "les défauts inhérents à une traduction proche historiquement de l'original, proximité qui empêche d'en saisir toute la complexité", and to work in the "cortège d'échos, de résonances et de références" brought to light by "près d'un siècle d'études sur l'oeuvre, son texte et son histoire". ${ }^{10}$ Another aim was to bring the language of the translation up to date for the benefit of a contemporary French audience: the back cover emphasizes the volume's ambition to create a text which will speak to "les générations d'aujourd'hui". These aspirations evidently mark a complete about-face in Aubert's stance. In 1995 he had argued that the 1929 translation was too permanent to change; in the postscript to the 2004 translation, he makes the case for the opposite approach, stating that a translation produced in 1929 is inevitably outdated, and irrevocably bears the marks of the language, aesthetics and ideology of its time. ${ }^{11}$

\footnotetext{
${ }^{7}$ The terms are Patrick O'Neill's, who notes that "in a number of languages there are early, "naïve" translations as well as second- or third-generation translations of much greater sophistication, drawing on decades of increasingly detailed international study of Joyce's literary output." - Polyglot Joyce: Fictions of Translation (Toronto, Buffalo and London: University of Toronto Press, 2005), p. 14.

${ }^{8}$ At a roundtable discussion entitled "Autour de la nouvelle traduction d'Ulysses", held in Tours on 15 June 2008 on the occasion of the XXI ${ }^{\text {st }}$ International James Joyce Symposium, Jacques Aubert named Antoine Gallimard (Director General of Les Editions Gallimard) and Stephen Joyce as the instigators of the new translation.

9 James Joyce, Ulysse, trans. under the direction of Jacques Aubert, "Du Monde Entier" (Paris: Gallimard, 2004) - hereafter abbreviated as Gallimard 2004.

${ }^{10}$ Gallimard 2004, p. 972.

${ }^{11}$ Gallimard 2004, pp. 972-3.
} 
The implications of the decision to re-translate both because of and in spite of the existence of an established precursor translation are teased out in the postscript to the 2004 edition. Aubert's comments on the difficulties that derive specifically from translating after an antecedent version has achieved high repute form a particularly informative part of his continuing debate with himself concerning the validity of the endeavour. Reader memory, as Aubert argues, can act as an obstacle to daring in translation, charging plans for departure from precedent with additional anxiety. Aubert cites the problems pertaining to proper names as an example of such difficulties. The urge to Gallicize proper names - a solution Joyce and Larbaud had favoured in their day ${ }^{12}$ - had to be kept in check for the sake of readers (or prospective readers) who have come, by 2004, to expect Buck Mulligan - rather than a more French-sounding counterpart - to enter from the stairhead, and Stephen Dedalus (rather than, say, Etienne Dédale) to join him atop the Martello Tower: "La mémoire que nous avons aujourd'hui du texte, en français comme dans sa langue originale (...) par exemple le nom des personnages principaux, nous ont interdit d'aller dans ce sens". ${ }^{13}$

The 2004 endeavour presents many peculiarities. It is not the work of a single translator, nor even of a small group. This team, with Aubert at its helm, comprised eight members. ${ }^{14}$ A text like Ulysses might incline one to think of strength in numbers as an asset. However, Aubert elected to distribute the book's episodes between the various translators. The team, that is, never worked together on the whole of the text (though regular meetings were held to discuss the project's progress and problems emerging in each member's designated corner of the work ${ }^{15}$ ). To justify this approach, Aubert invokes Joyce's insistence that each of Ulysses's eighteen episodes was writ-

${ }^{12}$ Gallimard 2004, p. 976. This preference was manifestly not taken into account.

${ }^{13}$ Gallimard 2004, p. 976.

${ }^{14}$ A "Liste des Traducteurs" is provided on the edition's very last page - Gallimard 2004, p. 981. The translators are: Jacques Aubert himself ("Telemachus" and "Wandering Rocks"), Michel Cusin ("Nestor"), Pascal Bataillard ("Proteus", "Lotus-Eaters", and "Eumaeus"), Marie-Danièle Vors ("Calypso"), Patrick Drevet ("Hades" and "Nausicaa"), Bernard Hoepffner ("Aeolus", Circe", and "Ithaca"), Tiphaine Samoyault ("Lestrygonians", "Sirens", "Cyclops", and "Penelope"), Sylvie Doizelet ("Scylla and Charybdis"). Morel's translation was retained in toto for "The Oxen of the Sun". Aubert rather perplexingly presents his team of translators as falling into three separate categories: "écrivains", "traducteur littéraire", "universitaires familiers de l'oeuvre de James Joyce" - Gallimard 2004, p. 975.

${ }^{15}$ Aubert is keen to assure the reader that the collaborative atmosphere which prevailed throughout the project ("l'occasion de partager des expériences et des savoirs" bore no likeness to the poisonous context of personal animosity that served as a backdrop to the 1929 translation - Gallimard 2004, pp. 974-5.

Scientia Traductionis, n. 8,2010 
ten in its own individual style and from a different point of view. This, he rather tenuously argues, lends support to "l'idée d'une traduction collective, dont l'avantage est d'éviter que le recours à un seul traducteur, si brilliant fût-il, ne donne à la lecture de l'oeuvre un infléchissement trop personnel et que le texte ne résonne d'une seule voix". ${ }^{16}$

This reluctance to risk unifying the polyphonic dimension of the text by having a single translator on the job causes Aubert to lose sight of the equally treacherous danger of failing to harmonize in such a way as to enable its numerous recurring motifs to ring in tune. ${ }^{17}$ In translating Ulysses, one of the greatest difficulties - the "greatest difficulty" according to Mogens Boisen - "consists in remembering the leitmotifs: there are thousands of them, often only a word, but it must be repeated maybe 700 pages later, and repeated either in the identical form or in some significant variation to which Joyce subjected it". ${ }^{18}$ Aubert's decision to retain Morel's translation of "The Oxen of the Sun" in toto further imperils belief in the possibility of this medley of voices producing an internally consistent translation. The fact that the admission of this wholesale borrowing is relegated to a mere footnote - in which Aubert asserts that the import from Morel's dated translation will prove "interesting"19 - does little to reassure.

The 2004 edition makes other intriguing choices. Aubert opts, for instance, to use the 1922 edition of Ulysses (in the reprint provided by Jeri Johnson in $1993^{20}$ ) as his translation's original or base text. There is no problem with such a choice per se, but if one of the new translation's objectives was to register the editorial and critical shifts that have punctuated and inflected Ulysses's reception since 1929, then the Gabler edition - currently the academic reference text - may have been a more obvious place to start. In stark contrast to the "Pléiade" volume, the 2004 edition does not include any annotation, allowing no space for the acknowledgement of the numerous meanings the translation necessarily occludes. On the other hand, this translation benefits from a free rein with typography, which enables it to remove

\footnotetext{
${ }^{16}$ Gallimard 2004, p. 975.

${ }^{17}$ At the roundtable discussion held in Tours on 15 June 2008, Aubert admitted that the decision to work on the project as a team entailed an "obligation du manque de rigueur", as rules adhered to in one episode (with respect to, say, word order and capitalization) were often deemed inapplicable in others.

${ }^{18}$ Mogens Boisen, "Translating Ulysses", James Joyce Quarterly, Vol. 4, No. 3 (Spring 1967), 165-9, 166.

19 "A cet égard, il nous a parut intéressant de conserver l'un des épisodes de cette traduction, celui dont précisément le style est constitué par une série de pastiches d'oeuvres littéraires allant du Moyen Age à nos jours." - Gallimard 2004, p. 992.

${ }^{20}$ James Joyce, Ulysses, ed. Jeri Johnson (Oxford: Oxford University Press, 1993).
} 
the commas and inverted commas that the 1995 "Pléiade" was obligated to add. $^{21}$

\section{The "Sandwich" passage in "Lestrygonians" $(U$ 8.741-754)}

[In this section of the essay Morel's translation and the translation overseen by Aubert in 2004 will be referred to as F/Morel ${ }^{22}$ and F/Aubert ${ }^{23}$ respectively.]

"Lestrygonians" holds a special place in the history of the French translations of Ulysses. Indeed, when Larbaud wrote to Sylvia Beach on 22 February 1921 to report ecstatically on his first encounter with Ulysses, his mind had already turned to the possibility of translation and seemingly identified the time spent by Bloom "in the restaurant" as being of particular interest:

Dear Sylvia, I am raving mad over "Ulysses". Since I read Whitman when I was 18 I have not been so enthusiastic about any book. I have read all there is in The Little Review (...) I think I should like to translate a few pages for "La N. R. F" or, if they don't want it, "Les Ecrits Nouveaux". Perhaps the place where Bloom is in the Restaurant. Just 8 or ten pages in all. Just to show how wonderful it is. ${ }^{24}$

The opening of the restaurant passage ( $U$ 8.732) - a phrase which this essay takes as a reference to "Lestrygonians" rather than to "Sirens" presents the translator with a hardy challenge, which may explain why the episode was not, in fact, among the first to be attempted in French ${ }^{25}$. Consi-

${ }^{21}$ Aubert draws attention to this fact in a postscript to his afterword: "Nous tenons à souligner que la typographie de la présente édition suit fidèlement celle de l'édition originale." - Gallimard 2004, p. 980.

22 "Pléiade" 2, pp. 193-4.

${ }^{23}$ Gallimard 2004, p. 217.

${ }^{24}$ Valery Larbaud, Lettres à Adrienne Monnier et à Sylvia Beach 1919-1933, ed. Maurice Saillet ([place of publication unknown]: I.M.E.C. Editions, 1991), p. 40.

${ }^{25}$ Whether Larbaud's phrase designates "Lestrygonians" or "Sirens" remains an open question. In a footnote to Larbaud's letter to Monnier, Saillet refers the reader to "Lestrygonians". Yet the passages of Ulysses first translated into French by Jacques BenoistMéchin (with help from Léon-Paul Fargue and in collaboration with Joyce himself) and revised by Larbaud ahead of his reading at Monnier's "La Maison des Amis des Livres" bookshop on 7 December 1921) were from "Sirens" and "Penelope". According to Monnier, the choice of passages was Larbaud's, but when this selection was made, and whether 
dering the appeal of a "Sandwich?", Bloom responds to his own question in his typically erratic, tangential way, musing that "Ham and his descendants musterred and bred there" ( $U$ 8.742-3). The sentence compounds Bloom's thoughts about food with a comic rhyme remembered from C.C. Bombaugh's Gleanings for the Curious from the Harvest Fields of Literature:

\author{
Why should no man starve on the deserts of Arabia? \\ Because of the sand which is there. \\ How came the sandwiches there? \\ The tribe of Ham was bred and mustered there. ${ }^{26}$
}

Part of the humour of this snippet of nonsense verse derives from its invocation of Ham, whose portrayal in the Bible as the father of the black races relates to the "Sandwich" passage's repeated allusions to tribal chiefs and colonial missionaries. F/Morel's attempt at the translation of these impossibly layered lines betrays an effort to retain the connection the rhyme establishes between familial bloodlines and sandwich ingredients: "Toute la famille Cochon emmoutardée chez madame Tartine". But "Cochon" (pig) is but an imperfect substitute for ham ("jambon"), and the comic vision of the Pig family visiting Mrs Toast conjures an image of social visits between clans which dispels the original text's focus on a single group of blood relations. "Emmoutardée", a coinage suggestive of mustardy entrapment, seeks to preserve the comic vein, if not the comic content, of Bloom's musings. The references to the quiz question Bloom has in mind, as well as to the biblical story shadowed in the answer to it, are entirely lost.

F/Aubert ${ }^{27}$ opts to distance itself from the strict letter of Joyce's English text in a bid to capture more of its allusive savour. The culinary details are changed, fish for flesh: "Lotte et sa descendance assaisonnnées ici et enfournées dans du pain". This is inspired and judicious. "Lotte" is a species of fish ("devilfish" in English), which sounds like the name - "Lot" or "Loth" (spellings vary in French) - given to Abraham's nephew in the book

he had not at first had "Lestrygonians" in mind, remains an open question - see "La traduction d'Ulysse", in Adrienne Monnier, Rue de L'Odéon (Paris: Editions Albin Michel, 1960), pp. 159-70.

${ }^{26}$ C.C. Bombaugh, Gleaning for the Curious from the Harvest Fields of Literature (Philadephia, 1890). See Ulysses Annotated: Notes for James Joyce's Ulysses, ed. Don Gifford with Robert J. Seidman, $2^{\text {nd }}$ and revd edn (Berkeley and Los Angeles, California, and London: University of California Press, 1989), p. 179. The source was first identified by Fritz Senn in the James Joyce Quarterly, Vol. 12, No. 4 (Summer 1975), 443-450.

27 The translation of the "Lestrygonians" episode for F/Aubert was undertaken by Tiphaine Samoyault. 
of Genesis. In The Bible, Lot and his family are saved from the destruction of Sodom by godly intervention. The condition for their safe carriage away from the burning city is that none of the escapees look back at the devastated city. Lot's wife does look back, and is duly turned into a pillar of salt. With their mother turned "too salty" (to use a phrase which appears within the "Sandwich" passage - U 8: 745-6), Lot's daughters decide that the only way to preserve the family line is for them to become pregnant by their own father. With this aim in mind, they ply him with alcohol and successfully have their way with him. Both eventually bear his children.

The rudiments of this biblical background (especially the story of the wife transformed into a pillar of salt) are key to the multilevel functionality of the shift from "ham" to "lot/te". The "Sandwich" passage opens with Bloom casting a glance at the "Sardines on the shelves. Almost taste them by looking" ( $U$ 8.740). It makes as much psychological sense for Bloom to think of another kind of fish ("lotte") when considering the appeal of a sandwich as it does for him to consider ham (he ultimately goes for neither fish nor flesh and chooses cheese). The logic of his interior monologue is not disrupted by the change. Furthermore, the biblical reference to Lot enables F/Aubert to translate "descendants" with its nearest French equivalent, "descendance": this captures the reference to biblical genealogies in a way in which "la famille Cochon" and "Madame Tartine" in F/Morel cannot. "Assaisonnées" is another felicitous find: mustard is lost, but spice is gained: "assaisonner" a dish is to add flavour to it by the addition of salt or pepper or spice. The potential reference to salt is brilliant, given the part it played in Lot's story, and the punishment dealt to his wife in retribution for her curiosity. The suggestion of spice also hints at the "spicy" details of Lot's sexually charged family history, which begins in Sodom and ends with incest. Moreover, the salty connotations of "assaisonnées" ring in tune with Bloom's reflections on the likely causes (according to a widespread cliché) for the survival in Africa of "[w] hite missionar[ies]": "too salty" for a cannibal's liking (U 8.745-6).

Lot's role in F/Aubert also befits the passage's intratextual connections to other parts of the book. The mention of "Plumtree's potted meat (...) $[\mathrm{u}]$ nder the obituary notices" in the following sentences echoes an earlier section of "Lestrygonians" in which Bloom entertains the same thought. At $U$ 8.138-9, we read: "His ideas for ads like Plumtree's potted under the obituaries, cold meat department". Moments before (two lines up the page in the Gabler edition), Lot's story had flitted through Bloom's mind: "Women too. Curiosity. Pillar of salt" $(U$ 8.136). Another allusion to Lot features in Bloom's interior monologue well before "Lestrygonians". As early as "Ca- 
lypso", Bloom has Sodom and Gomorrah, as well as Lot's wife's salty demise, on his mind: "the cities of the plain: Sodom, Gomorrah, Edom. (...) It bore the oldest, the first race (...) Cold oils slid along his veins, chilling his blood: age crusting him with a salt cloak" (U 4.222-224, 231-2). Although the burden of salty metamorphosis has shifted from Lot's wife to Bloom himself (as he mentally tunnels back through time to the beginnings of the oldest race Bloom is, like Lot's wife, and like Stephen at the end of "Proteus", "rere regardant" - U 3.503), the allusion is clear. There is plenty of textual justification, then, for Lot to appear at the level of allusion in F/Aubert's rendition of the "Sandwich" passage. The aptness of the Aubert team's chosen solution, however, is counterbalanced by the surplus that such a re-insertion of the motif provokes: the translation endows the Lot theme with more prominence than it is granted in the original text.

Where F/Morel translates "Plumtree's potted meat" $(U$ 8.743) with "pâtés Prunier", F/Aubert retains the English word in the phrase "conserves Plumtree". This choice is perplexing given how well the strictly literal translation - "Prunier" - works in F/Morel as an imaginary brand name. It is when Bloom remembers the editorial faux-pas that has led newspaper obituaries to be printed above the Plumtree's ad ("All up a Plumtree" - $U$ 8.744) that the word "prunier" proves most fruitful. Keeping the tree literal is important to the joke: F/Morel's "Tous fichus sur le prunier" produces the same imaged evocation of death and trouble (being hanged from a tree, or stuck up a tree) as the original. F/Aubert's "Tous fichus avec ou sans conserve" dispels the verve of the original idiom, evacuates the tree image, discontinues the joke regarding the newspaper's unwittingly tasteless layout, and alters the meaning of the original (which bears no hint of speculation as to whether the dead people whose names are listed were Plumtree's consumers or not). Perhaps this was one of those instances, mentioned in the postscript to the 2004 translation, in which Aubert's team decided that the reading public's foreknowledge of "Plumtree's" as one of Ulysses's catchwords got in the way of a new departure, demanding the direct transposition of the English brand name. On the other hand, the change goes against Aubert's argument that it was the influence of the first French translation which most impeded his team's freedom.

Both F/Morel and F/Aubert translate "home" with "maison". In F/Morel, the ad goes: "Qu'est la maison sans les pâtés Prunier?", while in F/Aubert, the question is turned into a statement: "Une maison n'est pas une maison sans les conserves Plumtree". In both cases, the use of the formal "maison", both the physical building and the private enclave of the home to 
which it gives shelter, loses something of the cosiness conjured by the English word and the ad ("What is home without Plumtree's potted meat").

F/Aubert translates "Expect the chief consumes the parts of honour" $(U$ 8.746) as "On attend du chef qu'il consomme les parties honorifiques". This is to miss the implications of the grammar of the Joycean original. If Bloom had been thinking about the tribe's expectations of its chief, the sentence would have begun: "Expect the chief to consume". It is clear from "Expect the chief consumes" that the conjecture is Bloom's. F/Morel captured this by using the same fronting verbal structure as the original: "Suppose chef consomme parties honorifiques".

F/Aubert's stated aspiration to update the French text is manifested in this passage by the change from the now relatively old-fashioned "réclame" ("Quelle réclame idiote!") for ad ("What a stupid ad"), to the contemporary "pub" ("Quelle pub imbécile"). "Pub" is short for "publicité" and thus neatly replicates the abbreviating gesture which shortens "advertisement" to "ad" in Bloom's interior monologue.

The curtailed (three lines rather than a regular five) limerick ("There was a right royal old nigger. Who ate or something the somethings of the reverend Mr MacTrigger" - U 8.748-9) is a site of difference between the two French translations. F/Morel follows the phonetic pattern of the English original, which rhymes the end of the first line, "nigger", with the end of the third line, "MacTrigger". ${ }^{28}$ In French, however, this adherence to the sound structure of the original is performed at the cost of the meaning of Joyce's rhyme, which establishes an unsettling connection between "nigger" and the missionary's "trigger". By contrast, F/Morel's rendering has to settle for a banal, meaning-free surname: "Il y avait un bon vieux roi moricaud. Qui chose ou mangea les choses du père Caud". The "Pléiade" annotates this passage, explaining what F/Morel occludes, and making a suggestion for a more suitable rendition: "Il s'agit d'un Pasteur de l'Eglise anglicane dont le nom a une consonance écossaise. Si l'on désire conserver les connotations belliqueuses, alliées à un symbolisme sexuel primaire, on peut traduire: 'Il y avait un roi nègre d'Eldoret, Qui mangea ou chosa les choses du révérend MacGâchette"." ${ }^{29}$

F/Aubert seems to have taken its cue from this suggestion. "Nigger" is translated literally as "nègre". The priest's name loses its Scottish inflection but captures the brutality of "trigger" literally with "gâchette". As these

${ }^{28}$ I refer to "lines" although the text of Ulysses makes no such concession to the form of the poem - traditional layout is sacrificed in keeping with the flow of Bloom's interior monologue.

29 "Pléiade" 2, p. 1348.

Scientia Traductionis, n. 8,2010 
words do not rhyme, the onus to do so is shifted to the middle line, and this leads to an addition ("en cachette") which has no semantic basis in the English original: "Il était un bon vieux roi nègre. Qui mangea ou chosa en cachette Les choses du révérend Lagâchette". ${ }^{30}$

There is one sentence in the "Sandwich" passage which clearly gave both translating teams particular trouble, with very illuminating consequences for the reader of both texts. The sentence in question is the following: "Cauls mouldy tripes windpipes faked and minced up" ( $U$ 8.750). Both translations appear to privilege the headwear-related meaning of "cauls". F/Morel begins with "De la coiffe": "De la coiffe des tripes gâtees des trachées mises en tas et hachées", while F/Aubert opens with "turbans": "Turbans de tripes pourries trachées tranchées truquées". These choices can seem surprising, for while the $O E D$ lists the first meaning of caul as that relating to headgear ("a kind of close-fitting cap, worn by women"), such connotations merely hover in the background in the context of the "Lestrygonians" passage, superseded by associations ushered in by "tripes windpipes faked and minced up". These bring to the acception of "caul" which denotes "the fatty membrane investing the intestines". The greater relevance of this sense of the word suggests misreadings by F/Morel and F/Aubert. But the choices made by both teams may in fact be more subtle than is immediately apparent: "coiffe" has specific uses relating to both anatomy and cooking, while "turbans" combines an image which summons the winding course of the intestines whilst also adumbrating a gastronomical reference (for "turbans" can designate a particular way of preparing food).

Other aspects of this anatomically focused sentence seem to have proved baffling to the French teams. Neither opts for the straightforward "moisi" for "mouldy", choosing instead to adopt the higher register "gâtées" (F/Morel) or the stronger "pourries" (F/Aubert). "Faked" also seems to have presented difficulties for both translations. The first meaning of the verb "to fake" is nautical and means "to lay (a rope) in fakes or coils; to coil". It is strange, then, that F/Morel should not have opted for anything more specific than the vague "mises en tas", which loses those suggestions of coiling which would replicate the connection implicitly established between the coiling of the tripes and the coiliness of the cauls of the intestine. More strangely still, F/Aubert appears to miss the first meaning of the verb "to fake", seemingly recognizing only in its more current acception, "to trick".

${ }^{30}$ The capitalization of "Les" in the 2004 translation breaks with both the original and the first French translation, in which the $2^{\text {nd }}$ "line" (demarcated from the first by a full-stop and the capitalization of its first word ("Who") flows seamlessly into what would normally be the third line of the limerick.

Scientia Traductionis, n. 8,2010 
Thus F/Aubert's tripes and windpipes are described as "truquées". F/Aubert also discards F/Morel's literal translation of "minced up" as "hachées" in a bid to imitate the English original's asyntaxical and alliterative enumeration of nouns ("cauls mouldy tripes windpipes") by way of an alliterative accumulation of past participles ("trachées tranchées truquées") which turns the culinary connotations of "minced up" into suggestions of brutality ("tranchées") - the idea being, perhaps, that such connotations chime with Bloom's thoughts on cannibal practices.

Given this willingness to attempt the restitution of syntactically unusual phrases, it is surprising that in translating "Yom Kippur fast spring cleaning of the inside" ( $U$ 8.752), F/Aubert should have felt compelled to introduce a comma where none was needed ("Le jeûne de Yom Kippour, le grand nettoyage de printemps"), thereby following F/Morel ("Jeûne du Yom Kippur, grand nettoyage de printemps des intérieurs").

The two translations differ significantly when it comes to Joyce's use of the biblical injunction to "Eat drink and be merry" ( $U$ 8.754). F/Morel is faithful to Joyce's original source, and goes back to Ecclesiastes to give "Mangez, buvez et tenez-vous en joie" (adding another comma to Bloom's comma-less thoughts). F/Aubert acts on its stated objective to bring the text up to date by opting for the more informal "Mangez, buvez et embrassez qui vous voudrez". This formula merges the biblical expression with the words of a popular children's song, "Nous n'irons plus au bois", the refrain of which closes with the invitation "Sautez, dansez, embrassez qui vous voudrez". Fascinatingly, the first words of the (originally eighteenth-century) song are: "Nous n'irons plus au bois, les lauriers sont coupés", providing a possibly voluntary connection (on the part of the French translators) between Bloom's thoughts and the book (Dujardin's Les Lauries sont coupés) which Joyce claimed had inspired the manner of their articulation. The allusive texture of the snippet is maintained (though the "content" of the allusion is changed) and the choice of a popular song as its intertextual referent remedies the rather stilted tenor of F/Morel's "tenez-vous en joie", which is considerably more formal than the English "be merry".

Finally, "mighty cheese" ( $U$ 8.755). F/Morel was produced without knowledge of the "mity" variant re-instituted by Gabler in 1984. F/Morel, therefore, is literal and straightforward: "Puissant fromage". Aubert's team, which worked from the text of the 1922 edition of Ulysses, need not have sought to accommodate the "mity" variant (which gets a mention in the scrupulous notes to the 1995 "Pléiade" edition ${ }^{31}$ ). Yet F/Aubert manages, by

\footnotetext{
31 "Pléiade" 2, p. 1349.
} 
an artful feat of linguistic imagination, to adumbrate the emendation of "mighty" to "mity" whilst also remaining faithful to the surreal vision of "mighty cheese" with which the paragraph drew to a close until 1984. ${ }^{32}$ F/Aubert opts for the phrase "Fromage qui marche tout seul", drawing on an idiomatic expression which refers to a cheese so mature - so full of mity bacteria - as to be literally mobile: a walking cheese. ${ }^{33}$

The two extant translations of Ulysses illustrate the extent to which translations respond to each other as well as to their shared original, constituting a self-revising system of interpretation. F/Morel and F/Aubert are both barking up the same (plum)tree, yet F/Aubert, which has the benefit of considerable hindsight, takes account of F/Morel at the same time as it scrutinizes Joyce's text: later translations are almost inevitably anchored in several texts at once, even if the ultimate commitment remains to the fullest possible rendition of the subtleties of the original. For all Aubert's reservations regarding the feasibility of translating after the first, "authorized" French Ulysse, the French Ulysses "system" "34 would benefit from the addition of at least two more versions. The first of these would, ideally, be a translation less hampered than F/Aubert by a sense of allegiance to the canonical 1929 version. The second would take Gabler's 1984 edition - currently the reference edition for academic articles - as its base-text, and thus provide an editorially, as well as lexicographically, updated version of Ulysses in French.

Scarlett Baron

scarlett.baron@chch.ox.ac.uk Magdalen College, Oxford

32 At the roundtable discussion held in Tours on 15 June 2008, Aubert mentioned his team's occasional efforts to reflect emendations instituted by the Gabler edition.

${ }^{33}$ My thanks to Daniel Ferrer for drawing my attention to the meaning of this French idiom.

${ }^{34}$ I use this phrase in the acceptation put forward by Patrick O'Neill, who explores "the notion that there are interesting ways in which the entire corpus of Joyce translations can be regarded as a single and coherent object of study (...) constituting, together with their originals, a single polyglot macrotext": "the Joyce system" - Polyglot Joyce, pp. 3 and 9. In a separate article, O'Neill articulates a transtextual model of interpretation which "reads translations as continuations and extensions, individually and collectively, of the original text" (p. 257): "The sum of their differences from each other as well as from the original text, serves to enrich and to extend the literary text that Joyce first set in motion" (p. 270) "Extending the Text, Textuality and Transtextuality", in Joyce on the Thresold, ed. Anne Forgarty and Timothy Martin (Gainesville: University Press of Florida, 2005), pp. 255272 , pp. 257 and 270.

Scientia Traductionis, n.8, 2010 